\title{
TELAAH THE HOLY QUR'AN KARYA ABDULLAH YUSUF ALI
}

\section{Sulaiman Ibrahim}

IAIN Sultan Amai Gorontalo, Jl. Gelatik 1 Gorontalo e-mail: emand_99@hotmail.com

\section{Abstract}

This article deals with The Holy Qur'an, a book of translation and of a quranic exegeses written by Abdullah Yusuf Ali. This book becomes popular since it not only uses international language (English), but also possesses its own characteristics which make it different from other books of exegeses. The Holy Qur'an is so dominant in its sufistical commentary that it employes esetoric hermeneutics over the symbols existing in the Qur'an. In addition, this book employs lexical, grammatical, contextual, and social-cultural meanings that convey message that the translator depends on the standard language of the Qur'an. Abdullah Yusuf Ali obey does not the literal meanings of the verses, but he puts stongger emphases on its spiritual meanings.

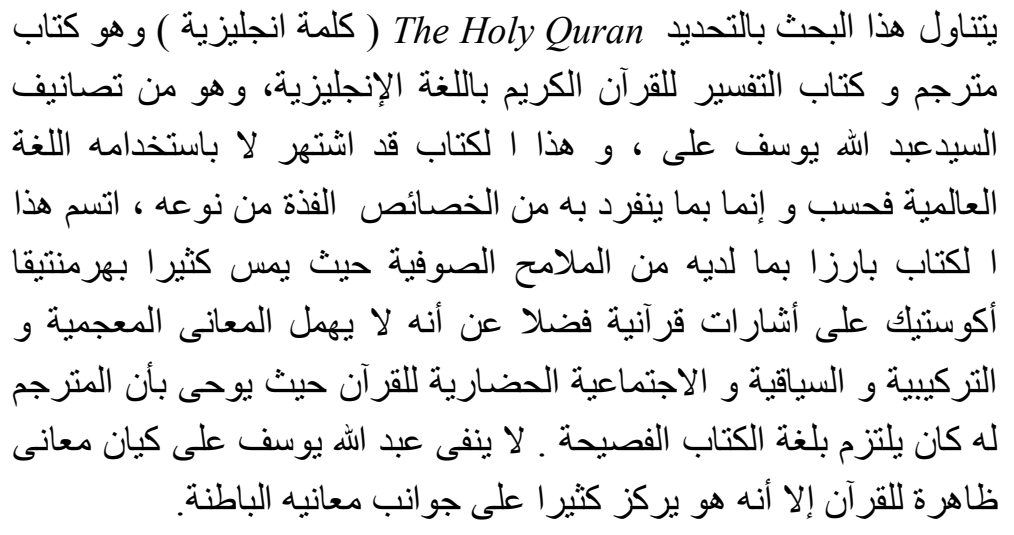

Kata Kunci: The Holy Qur'an, Abdullah Yusuf Ali, kitab tafsir 


\section{PENDAHULUAN}

Tafsir merupakan ilmu syari'at yang agung dan tinggi kedudukannya. Ia merupakan ilmu mulai yang objek pembahasan dan tujuannya, serta sangat dibutuhkan sepanjang zaman, karena manusia memerlukan petunjuk ilahi. Tanpa tafsir, seorang muslim tidak dapat menangkap mutiara-mutiara berharga dari ajaran Tuhan yang terkandung dalam Alquran.

Setidaknya ada tiga segi yang membuat dan menentukan tingginya kedudukan tafsir. Pertama, bahwa bidang yang menjadi objek kajian tafsir adalah kalam Allah yang mulia yang merupakan sumber segala ilmu agama dan keutamaan. Di dalamnya terhimpun berbagai aturan untuk kebaikan hidup manusia; kedua, tujuannya adalah untuk mendorong manusia berpegang teguh dengan Alquran dalam usahanya memperoleh kebahagiaan sejati, dunia dan akhirat; dan ketiga, dilihat dari kebutuhan pun sangat jelas bahwa kesempurnaan mengenai bermacam-macam persoalan, baik agama maupun keduniaan, memerlukan ilmu syari'at dan pengetahuan mengenai seluk-beluk agama (Shihab, 2002). Hal itu sangat bergantung pada ilmu pengetahuan tentang Alquran, yaitu tafsir.

Banyak statemen Alquran yang sulit dipahami kecuali telah dikonsultasikan pada teks yang lain melalui para ahlinya. Persoalan ini sudah mulai dirasakan di zaman sahabat nabi sendiri dalam kitab-kitab klasik, dikemukakan contoh bagaimana sahabat nabi memerlukan datang ke orang Badui (pedalaman Arab) untuk melakukan riset bahasa, ketika dikemukakan kata-kata asing dalam Alquran, yang lebih dikenal dalam masyarakat pedalaman (Hidayat, 2004:148).

Redaksi ayat-ayat Alquran, sebagaimana setiap redaksi yang diucapkan atau ditulis, tidak dapat dijangkau maksudnya secara pasti, kecuali oleh pemilik redaksi tersebut. Hal ini kemudian menimbulkan keanekaragaman penafsiran. Dalam hal Alquran, para sahabat nabi sekalipun, yang secara umum menyaksikan turunnya wahyu, mengetahui konteksnya, serta memahami secara alamiah struktur bahasa dan arti kosakatanya, tidak jarang berbeda pendapat, atau bahkan keliru dalam pemahaman mereka tentang maksud firmanfirman Allah swt. yang mereka dengar dan mereka baca itu (Shihab,1996:75). Dari sini kemudian para ulama menggarisbawahi 
bahwa tafsir adalah penjelasan tentang arti atau maksud firman-firman Allah sesuai dengan kemampuan manusia (mufasir).

Bahwa setiap hasil pemikiran seseorang dipengaruhi bukan saja oleh tingkat kecerdasannya, tetapi juga oleh disiplin ilmu yang ditekuninya, baik melalui pengalaman, penemuan-penemuan ilmiah maupun kondisi sosial, politik dan sebagainya. Oleh karena itu, hasil pemikiran seseorang akan berbeda satu dengan lainnya.

\section{PROFIL MUFASIR}

\section{Biografi Abdullah Yusuf Ali}

Abdullah Yusuf Ali dilahirkan pada tanggal 4 April 1874 di sebuah kota tekstil di Gujarat, India Barat, yang menjadi kresidenan Bombay pada masa kejayaan Raj (Sherif, 1994:18). Ia adalah putra kedua dari ayahnya, Yusuf Ali Allabus atau Khanbahadar Abdullah Yusuf Ali seorang anggota kepolisian surat. Ibunya meninggal ketika ia masih bayi dan ia tidak sempat mengenal ibunya sehingga kasih sayang ibu lepas dari kesadarannya. Ia pun tidak pernah menyinggung ibunya sementara ayahnya yang membesarkan dan mendidiknya selalu diingat-ingat bahkan suatu ketika ia menulis pengantar karya tafsirnya, The Holy Qur'an, pada usia 62 tahun (Ali,1989:ix). Rabu 9 Desember 1953 Yusuf Ali pikun, ditemukan duduk di depan sebuah rumah di Westminister Inggris, kemudian polisi membawanya ke rumah sakit pada saat itu juga. Untuk sementara dia dipindahkan ke sebuah panti jompo London Country di Dovehouse/Chelsea. Serangan jantung yang dialaminya keesokan harinya, pada 10 Desember, mengharuskan ia dibawa ke rumah sakit St. Sthephenis Fulhan. Tiga jam kemudian, ia wafat tanpa seorang pun sanak keluarga yang menyertainya. Delapan puluh satu tahun masa hidupnya dijalani di India dan Inggris berkarir di pemerintahan India dan Inggris. Menikah dua kali dengan dua wanita Inggris dan seperti seniornya, Ahmad Khan, ia membela kepentingan umat Islam dengan penuh loyalitas. Dalam kehidupan pribadi, sosial bahkan keagamaan, Abdullah Yusuf Ali berupaya memadukan Barat dan Timur, sebuah idealisme yang rumit dan penuh tantangan ingin ia wujudkan dalam kepribadian dan pemikiran. Sosok Abdullah Yusuf Ali merupakan tokoh yang populer di kalangan umat Islam India dan dipandang sebagai wakil umat muslim paling utama dalam pandangan India Inggris. Namun demikian, ia tidak 
mendapatkan popularitas yang sepadan dalam kalangan pembaru muslim India, sehingga namanya hampir-hampir tidak tercatat dalam pembaruan Islam India. Ia menebus kekurangan tersebut dengan reputasi luar biasa dengan menciptakan karya tafsir The Holy Qur'an yang hampir menembus seluruh penjuru dunia Islam (Ali,1989:1-4).

\section{Pendidikan Abdullah Yusuf Ali}

Pendidikan dalam keluarga yang melibatkan secara intensif kepedulian orang tua dengan segenap kemampuannya, diyakini oleh para tokoh pendidikan sebagai periode pertama dalam keseluruhan episode perkembangan manusia, juga tidak disangkal akan pentingnya peran pendidikan sekolah dalam pembentukan kepribadian manusia. Bahkan ada keyakinan bahwa karena sifat sekolah yang begitu teratur dan terstruktur, pendidikan sekolah memberikan sumbangan yang paling berarti bagi manusia, tetapi pendidikan di luar sekolah tidak begitu saja dapat diremehkan, terutama di lingkungan luar sekolah dan pascasekolah merupakan kesempatan yang lebih luas dan lebih alamiah, sudah barang tentu akan memantapkan hasil-hasil pendidikan lainnya, termasuk pendidikan di bangku sekolah. Bahkan proses penghayatan akan nilai-nilai pengetahuan dan keterampilan justru lebih banyak dilakukan pada masa prasekolah.

Sejalan dengan tumbuhnya lembaga-lembaga dan munculnya para cendekiawan muslim, gagasan memasuki pendidikan sekolah mejadi suatu keharusan. Pendidikan sekolah tampaknya akan sangat menentukan prestasi dan prestise seseorang di masa depan. Tampaknya, Yusuf Ali menyadari akan pentingnya pendidikan sekolah. Tampaknya ayah Abdullah Yusuf Ali memiliki rencana tertentu untuk memutuskan Abdullah Yusuf Ali untuk bersekolah di Bombay.

Di Bombay, Abdullah Yusuf Ali memasuki Anjuman el-Islam pada tahun 1881, saat ia berusia 9 tahun. Setelah itu, ia mengikuti pendidikan di Wilsoris School (1884-1887), Wilsoris School Bombay (1887-1891). Di bawah pemerintahan Inggris, ia melanjutkan pendidikan ke St. Jhon University Cambridge, dengan program studi ilmu hukum. Tidak ada pengalaman sia-sia dari perjalanan Abdullah Yusuf Ali, semua pengalamannya menjadi sangat berarti, karena 
semuanya dihayati dan membekas pada kepribadiannya, pengalaman pendidikan sekolah menjadi momen yang secara kuat membentuk karakter dan pemikiran-pemikiran Abdullah Yusuf Ali, dan ini akan menjadi jelas dari analisis pengalaman belajarnya di setiap jenjang pendidikan sekolah. Anjuman el-Islam adalah organisasi keagamaan muslim di Bombay, dan sekolah Anjuman merupakan sekolah pertama di Bombay pada masa rekonstruksi kelembagaan muslim. Gagasan yang melatarbelakangi pendirian Anjuman tampak lulus dari rumusan tujuan Anjuman, yaitu memajukan komunitas, meningkatkan pendidikan moral dan keadaan sosial mereka. Para murid sekolah Anjuman datang dari berbagai daerah, sebagai pengaruh prefiksi dari popularitasnya. Di antara yang menjadi murid sekolah Anjuman selain Abdullah Yusuf Ali adalah anak-anak Tayebji bersaudara dan Muhammad Ali Jinnah (Ali,1989:4).

Faktor terpenting dari sistem pendidikan di Anjuman adalah faktor etos kerja yang secara sengaja dikembangkan, yaitu mengejar kualitas dan berorientasi ke depan. Anjuman berobsesi menjadi wadah persatuan umat muslim dari berbagai kelompok sosial, politik, dan ekonomi.

Abdullah Yusuf Ali mempunyai catatan akademis cemerlang di Wilson School. Ia meraih nilai tertinggi untuk wilayah Bombay pada usia 14 tahun, kemudian mencapai gelar BA. nomor satu dari Universitas Bombay pada bulan Januari 1891, dalam mata kuliah sastra Yunani kuno. Dia memenangkan hadiah dan terpilih untuk menerima beasiswa Dakshna dalam sejarah Yunani di Collegenya. Pemerintah Bombay memberikan beasiswa untuk melanjutkan studinya ke Inggris selama 3 tahun masa belajar di Cambridge, University College London. Sebagai mahasiswa di Cambridge, ia melewatinya dengan penuh suka dan duka. Bertahun-tahun yang ia lewatkan di sana telah mejadikannya mahasiswa dalam pengertian yang sebenarnya, membangkitkan hasrat yang tak kunjung terpuaskan dalam dirinya untuk mencari pengetahuan dan kecintaan untuk selalu belajar.

Semangat jiwa Anjuman yang khas berpengaruh terhadap perkembangan Abdullah Yusuf Ali adalah semangat juang membela kepentingan bersama umat Islam. Dan yang membentuk keyakinan dirinya adalah nilai-nilai pendidikan yang diterimanya di Wilson School dan Welson College. Lembaga pendidikan ini adalah lembaga 
misionaris yang didirikan oleh John Wilson, seorang pendeta dari Scotlandia yang ahli dalam bidang bahasa, sejarah purbakala di India Barat serta penerjemah Bible ke dalam bahasa Maratsi (Sherif,1994:7).

\section{Karir Abdullah Yusuf Ali}

Karir Abdullah Yusuf Ali diawali setelah ia menyelesaikan kuliah hukumnya di St. John University, Cambridge, yaitu dengan mengikuti pendaftaran pegawai negeri India (Indian Civil Service) pada tahun 1894. Pengumuman kelulusannya pada tahun 1895, dan mulai melaksanakan tugas pada tahun berikutnya, yaitu pada tahun 1896 di United Province (UP), India. Masa karir merupakan masa penuh dinamika yang melibatkan berbagai aktivitas publik dan pembicaraan intelektual Abdullah Yusuf Ali (Ali,1980:12).

Istilah "karir" dalam bahasan ini dapat dibedakan menjadi dua, yaitu karir berjenjang dengan karir tidak berjenjang. Karir berjenjang adalah karir yang dijalani Abdullah Yusuf Ali dalam struktur pegawai negeri, sedangkan karir tidak berjenjang adalah kiprahnya dalam berbagai forum ilmiah dan keterlibatannya dalam organisasi dan lembaga-lembaga pemerintahan dan swadaya masyarakat. Abdullah Yusuf Ali menjalankan tugas pertamanya sebagai asisten hakim dan kolektor di Saharanpur United Province pada tahun 1896. Dua tahun kemudian, tahun 1898, ia pindah tugas ke Rae Barelly-daerah tempat kelahiran tokoh mujahidin Sayyid Ahmad Syahid-dekat Aligarh. Dengan demikian, Abdullah Yusuf Ali menjadi dekat dengan tempat berdirinya Muhammadan Anglo Oriental College atau dikenal dengan MAOC yang didirikan oleh Sayyid Ahmad Khan pada tahun 1878. Ia pun merasa bersyukur karena dapat berhubungan dengan Sir Sayyid Ahmad Khan, kendatipun hubungannya sangat singkat karena Sayyid meninggal dunia pada tahun itu juga (Sherif,1994:32,317).

Pada tahun 1905, Abdullah Yusuf Ali cuti selama dua tahun. Selama itu pula ia memanfaatkannya untuk mengunjungi Inggris.Ia kemudian memberikan kuliah di lembaga berpengaruh, Royal Society of Arts pada tahun 1906. Ia kemudian dipilih menjadi anggota Royal Society of Arts dan Royal Society of Literature, sebuah posisi yang 
juga menyimpan pengakuan terhormat bagi seorang India di lembagalembaga yang dikuasai oleh orang-orang Inggeris dan Eropa pada umumnya.

Setelah cuti, Abdullah Yusuf Ali berakhir pada awal 1907, ia kembali menjalankan pekerjaannya di jajaran ICS sebagai wakil komisaris di Sultanpur. Karena alasan-alasan pribadi, ia mengakhiri karirnya di ICS dengan mengajukan surat pengunduran diri kepada pemerintahan Inggris pada 1914. Namun demikian, ia masih terus berkiprah secara intensif dalam berbagai kegiatan publik. Banyak karya tulisnya yang lahir pada periode pasca-ICS ini, dan salah satunya adalah tafsir The Holy Qur'an.

\section{Intelektualitas Abdullah Yusuf Ali}

Pemikiran modern Islam menampakkan modus perhatian yang berfokus pada masalah-masalah kontemporer umat Islam di bidang sosial politik dan ekonomi. Aktivisme Islam melibatkan ilmu pengetahuan dan teknologi Barat, seiring dengan meningkatnya pengaruh-pengaruh pemikiran dan lembaga-lembaga Barat kepada kehidupan umat Islam India. Abdullah Yusuf Ali adalah salah seorang cendekiawan muslim India yang berpendidikan Barat dan mengabdi sepenuhnya kepada Barat. Namun demikian, kompleksitas pribadinya, termasuk pemikirannya, dibentuk tidak hanya oleh pengalaman hidup dan pendidikan pada masa kecilnya, tetapi juga oleh peran-peran yang dimainkannya dalam panggung sosial politik dan pendidikan umat Islam India di bawah bayang-bayang kekuasaan Inggeris dan kekuatan umat Hindu.

Abdullah Yusuf Ali menjadi pelindung Universitas Osmaniyah yang didirikan pada tahun 1918, dan menarik banyak sarjana dari seluruh India. Ia berpartisipasi dalam banyak kegiatan di biro penerjemahan buku-buku teks dan literatur ilmiah dari bahasa Inggeris ke bahasa Urdu.

Di Lucknow, Abdullah Yusuf Ali berperaktik sebagai pengacara, dia juga seorang sastrawan, dengan kedua profesi itu, didukung dengan kemampuan berpidato yang hebat, telah menjadikannya manusia panggung yang selalu tampil di depan publik. 
Lebih dari itu ia juga mempunyai kemampuan menulis dan meneliti yang cukup produktif.

\section{Karya-karya Abdullah Yusuf Ali}

Abdullah Yusuf Ali dikenal memiliki beragam minat dalam berbagai bidang pemikiran, mulai dari sastra, hukum sampai kepada bidang pendidikan dan keagamaan. Sesuai dengan minatnya yang beragam, ia menulis dalam bidang yang sangat bervariasi dan menggunakan berbagai sumber yang dipandangnya relevan. Sumbersumber bacaannya sangat ekspansif sejalan dengan ketekunan dan minat bacanya yang sudah terbentuk sejak masa pendidikan awal. Sebagian ia menulis untuk proyek-proyek tertentu, terutama dalam hubungannya dengan tugas-tugas yang terkait dengan jabatan maupun ketika ia diminta menyampaikan pidato dan kuliah. Abdullah Yusuf Ali juga menyumbangkan berbagai tulisan dalam bentuk buku, artikel, pidato resmi, termasuk kuliah-kuliahnya di berbagai perguruan tinggi, jurnal maupun dalam bentuk entri untuk ensiklopedi.

Menurut Sherif, ada 125 tulisan Abdullah Yusuf Ali yang dipublikasikan di antaranya (Ali,1980:219-229):

- "Kehidupan Warga Negara di India" Imperial and Asiatic Quarterly Review (Januari-April 1906)

- Life and Labour of the People of India, (London: John Murray, 1907, tebal 360 halaman. Buku ini merupakan persembahan untuk Sir George Birdwood, dicetak ulang di Lahore: al-Biruni, 1977.

- Anglo Muhammadan Law, oleh R.K Wilson. Edisi ke-5 oleh Abdullah Yusuf Ali (Kalkutta: Thracker \& Spink, 1921)

"Orientalisme Goethe", The Contemporary Review. Jil XC (Agustus 1906)

- Muslim Education Ideals, (Lahore: Muslim Outlook, 1923)

- The Making of India; a Brief History, (London: Black, 1923)

- The Fundamental of Islam, diterbitkan dalam Sufi Quarterly, Jenewa, 1929

- Personality of Muhammad, (Pamplet Islam Progresif, 1929)

- Religious Polity of Islam, (Pamplet Islam Progresif, 1929)

PROFIL TAFSIR 
Deskripsi dan Analisis The Holy Qur'an: Text, Translation and Commentary

Kehidupan Abdullah Yusuf Ali mendatangkan banyak kejutan. Trauma emosional karena penyelewengan isterinya, Teresa Shalders, pada 1911 dan permusuhan anak-anak hasil perkawinan pada tahun 1920, mengubah persepsi Abdullah Yusuf Ali. Perasaan keagamaannya menyala kembali. Ikatan Abdullah Yusuf Ali dengan Alquran terbentuk pada masa-masa kemarahan ketika sedang mencari penghibur hati. Pesan Alquran menjadi pertolongan dan harapan yang paling menarik Abdullah Yusuf Ali.

Peristiwa ketika Abdullah Yusuf Ali menemukan Alquran di masa-masa penuh tekanan itu tidak hanya dikemukakan secara langsung dalam kata pengantar untuk The Holy Qur'an, melainkan juga pada beberapa tempat dalam ulasannya. Ada gambaran tentang betapa banyak pergolakan batin yang hebat ternyata merupakan kabar baik akan datangnya pemahaman spiritual yang mensucikan jiwa dan menyuburkan kehidupan spiritual yang dulunya gersang bagaikan padang pasir. Baginya agama menjadi urusan kesalehan pribadi.

Seluruh dunia fenomenal itu adalah suatu lambang, sedangkan realitas ada di baliknya. Keasyikan intelektual semacam ini mendorong Abdullah Yusuf Ali untuk terus menerus mencari lambang dalam ayat-ayat Alquran. Umpamanya ikan menjadi lambang bagi pengetahuan sekuler, matahari menjadi acuan mistik, bagi akal dan garas adalah lambang bagi misteri yang paling tersembunyi. Ada banyak penjelasan mengenai acuan Alquran pada air dan cahaya dan huruf yang disingkat atau muqatta'at.

Keahlian Abdullah Yusuf Ali menerjemahkan dan mengulas Alquran merupakan karyanya yang paling masyhur. The Holy Qur'an: Text, Translation and Commentary telah membuat namanya dikenal di dunia muslim. Penerjemahan, ulasan, lampiran dan tafsir yang ditulis dalam gaya syair yang tak bersajak atau dalam bentuk prosa yang ritmik.

The Holy Qur'an: Text, Translation and Commentary yang menjadi subjek pembahasan dalam tilisan ini terdiri atas: 
Prakata edisi pertama ditulis oleh Abdullah Yusuf Ali pada tanggal 4 April 1934 M. bertepatan dengan tanggal 18 Dzulhijjah $1352 \mathrm{H}$. di Lahore. Prakata ini berisi penjelasan sejarah proyek penerjemahan ini, rencana kerjanya, serta sasaran yang menjadi tujuan Abdullah Yusuf Ali yang tidak terlepas dari curahan hatinya.

Yang ingin disajikan oleh Abdullah Yusuf Ali adalah terjemahan bahasa Inggris yang berdampingan letaknya dengan teks bahasa Arab. Terjemahan bahasa Inggris ini tidak sekedar menukar sebuah kata dalam bahasa Arab dengan kata yang lain dalam bahasa Inggris, tetapi dengan mengungkapan sebaik mungkin untuk mengeluarkan makna sepenuhnya sebagaimana yang dimaksud dari bahasa Arabnya. Abdullah Yusuf Ali sangat mengusahakan irama musik dan nada bahasa asalnya yang begitu agung dan indah memantul dalam terjemahan ini, sehingga pembaca dapat membacanya bukan hanya dengan mata, lisan dan suara, tetapi juga dengan cahaya yang mengisi intelek manusia, bahkan dengan cahaya yang paling dalam dan murni yang diberikan oleh hati nurani dan kesadaran batin manusia. Wajarlah bila karya ini sangat monumental, karena Abdullah Yusuf Ali telah berkelana, rihlah ilmiyah, membuat catatan-catatan, menemui tokoh-tokoh dan menggali pikiran dan hati mereka untuk melengkapi tugas ini. Lebih dari empat puluh tahun cita-cita ini berkecamuk dalam pikirannya.

Teks bahasa Arab yang dicetak dengan rasm Utsmani terlihat perbedaannya dalam jalur yang berhadapan. Setiap surah dan ayat diberi angka tersendiri yang terdapat pada setiap halaman. Sistem pemberian angka ayat-ayat sebagian besar menurut edisi Mesir.

Adapun sistem penggunaan angka 'ayn dipakai seperti umumnya yang dipakai dalam naskah-naskah bahasa Arab dengan judul "Section". Alat Bantu lain untuk menunjukkan angka bagian masing-masing 'ayn dengan awal huruf kapital yang dicetak tebal. Sedangkan catatan mempunyai peranan penting dalam dalam terjemahan ini. Mengenai soal yang pokok, penjelasan diperoleh dalam catatan. Apabila ia meninggalkan penerjemahan harfiah, tiada lain dimaksudkan untuk menekankan pada semangat aslinya yang lebih baik dalam bahasa Inggeris karena hal ini dijelaskan dalam catatan. 
Rangkuman bernomor urut (running commentary) dari satu sampai tiga ratus, diawali dengan introduction diakhiri dengan conclusion. Rangkuman ini disusun dengan gaya syair yang tidak bersajak. Catatan kaki dimulai sejak dari nomor satu dalam rangkuman 19 pada halaman 5, bukan dimlai dari teks bahasa Arab sampai dengan 6311 dalam rangkuman "conclution" pada halaman 1811.

Manakala surah itu panjang, pokok bahasannya didahului dengan rangkuman tafsir dalam paragraf pendek yang disesuaikan tempat dengan ayat-ayat tertentu. Huruf rangkuman dicetak lebih kecil dari pada teks bahasa Inggris. Setiap surah diberi nomor, dilanjutkan dengan jumlah ayat dari surah yang bersangkutan, sedangkan nama surah diberikan dalam bahasa Arab di sebelah kanan yang diantara keduanya adalah angka yang menunjukkan halaman.

Selanjutnya, setiap surah juga diawali dengan pengantar singkat (introduction) tentang isi surah yang akan dibahas, seperti halnya surah pada umumnya terjemahan Alquran atau tafsir. The Holy Qur'an: Text, Translation and Commentary tidak selalu mempunyai penutup. Sebagai contoh dapat dilihat introduction surah al-Baqarah dan penutupnya dengan appendix 1, tetapi di akhir surah Âli 'Imrân tidak terdapat appendix. Hal ini disebabkan karena bergantung kebutuhan surah yang bersangkutan pada penjelasan dalam appendix terkait.

Terjemahan yang begitu luas mengharuskan dia merujuk beberapa buku acuan. Abdullah Yusuf Ali membagi buku-buku acuan ini ke dalam dua kategori, kategori pertama, terdiri atas (1) kitab-kitab terdahulu, (2)terjemahan yang sudah ada, dan (3) Kamus-kamus dan buku-buku acuan umum yang mudah diperoleh. Kategori kedua, adalah rincian dari bagian ketiga dalam kategori pertama, yaitu: (1) alMufradât karya Abû al-Qâsim al-Husaynî Râghib al-Isfahânî, sebuah kamus bahasa Arab tentang kata-kata dan ungkapan-ungkapan dalam Alquran, (2) Qâmûs, sebuah kamus bahasa Arab yang terkenal, (3)Lisân al-Arab, juga sebuah kamus bahasa Arab yang cukup terkenal, (4) Sûrah, sebuah kamus Arab-Persia, (5)Dictionary and Glossary of the Koran karya J. Penrice, (6) English-Arabic Lexicom oleh E.W. Lane, (7) al-Itqân fî̀ 'Ulûm al-Qur'ân oleh Jalâl al-Dîn al- 
Sayûț̂i, sebuah ensiklopedia Alquran yang sangat luas, (8)Geschichte des Qorans oleh Noldeke Und Schwally, sebuah esei bahasa Jerman mengenai kronologi Alquran yang kritik-kritik dan kesimpulankesimpulannya dari pandangan orang non muslim, (9)Encyclopedia of Islam, (10)Encyclipedia Britanica, edisi keempat belas, yang menjadi acuannya adalah pengetahuan tentang dunia Arab, (11)Dictionary of Islam oleh Hughes, sebuah kamus yang telah kadaluarsa tetapi masih berguna sebagai acuan, (12) Sirat al-Rasûl oleh Ibnu Hisyam tentang sejarah rasul secara rinci, (13) Sirat al-Nabi oleh Maulana Syibli Nu'mânî (w.1914 M/1334 H) sebuah sejarah hidup Rasulullah dalam bahasa Urdu, (14)Fath al-Rahmân oleh Faidullah Bek Hasani, sebuah konkordansi Alquran dalam bahasa Arab cetakan Cairo tahun 1346 (Ali,1980:24).

Sebenarnya, terjemahan Alquran sudah ada sejak lama dan diterjemahkan ke dalam beberapa bahasa, baik dalam bahasa-bahasa Eropa maupun dalam bahasa Timur. Terjemahan Alquran di luar bahasa Eropa, yaitu ke dalam bahasa Persia, Turki, Urdu, Tamil (biasa dipakai oleh orang-orang Mopla), Pashto (dipakai oleh orang-orang Afghanistan), Bengali, Melayu, bahasa kepulauan Nusantara, dan beberapa dalam bahasa yang dipergunakan di Afrika, dan diduga juga dalam bahasa Cina.

Terjemahan Alquran dalam bahasa Urdu yang paling tua ditulis oleh Syaikh 'Abd al-Qadîr (w.1826) di New Delhi. Selanjutnya, terjemahan dalam bahasa ini ada yang sudah selesai, ada pula yang belum. Yang sudah selesai diterjemahkan dan banyak dipakai orang, di antaranya, oleh Syaikh Rafiuddin, New Delhi, Syaikh Asyraf Ali Sanawi dan Maulana Nazir Ahmad (w.1912).

Sebelum bahasa-bahasa Eropa modern berkembang, bahasa baku pada waktu itu adalah bahasa Latin. Terjemahan dalam bahasa latin dilakukan untuk keperluan Biara Clugny kira-kira tahun 1143 M., yaitu pada abad VI hijriah dan diterbitkan pada tahun 1542. di Basle diterbitkan oleh penerbit Bibliander. Sedangkan Maracci telah menghasilkan terjemahan pada tahun 1689 dengan nash bahasa Arabnya beserta kutipan-kutipan dari berbagai tafsir dengan pilihan cermat untuk dikacaukan agar memberi kesan seburuk mungkin tentang Islam kepada Eropa. Penerjemahan ini adalah seorang pendeta yang berhak menerima pengakuan dosa pada Paus Innocent XI dan 
mempersembahkan pada Maharaja Leopald I dengan kata pengantar Kepalsuan Alquran. Lebih lagi, terjemahan George Sale, diterbitkan pada tahun 1734 dan didasarkan pada versi Latin terjemahan Maracci. Mengingat sasaran Maracci ini untuk memburukkan Islam di Eropa, suatu hal yang luar biasa, terjemahan Sale ini dipandang sebagai terjemahan baku dalam bahasa Inggris sehingga dimasukkan dalam Serial Chandos Classics dan direstui oleh Sir E. Denisson Ross. Lain halnya pendeta J.M. Radwell telah membuat terjemahan dengan susunan surah-surah secara kronologis sembarangan dan diterbitkannya pada tahun 1861 sebagai edisi pertama. Walaupun ia telah menyajikannya dalam ungkapan-ungkapan yang baik, catatancatatannya memperlihatkan cara berpikir seorang pendeta Kristen.

Dari bahasa modern baku ini, Alquran berkembang dan diterjemahkan ke dalam berbagai bahasa, di antaranya bahsa Itali, Jerman, Belanda, Prancis dan Rusia. Terjemahan dalam bahasa Jerman dilakukan oleh Schweiggerg, diterbitkan pada tahun 1647 di Nurenburg Bavaria. Jejak Schweiggerg ini diikuti oleh Boysen pada tahun 1773.

Menurut Abdullah Yusuf Ali, di dunia ini tidak ada kitab yang penanganannya begitu banyak menuntut keahlian, begitu banyak meminta tenaga, waktu dan biaya seperti dilakukan orang terhadap Alquran.

Mutu karya-karya semacam ini secara berangsur-angsur menurun sehingga tidak memenuhi kebutuhan dan keinginan masyarakat Islam, tetapi kebangkitan Islam mendorong dan diharapkan menghilangkan segala rintangan untuk memperoleh pikiran dan perhatian yang lebih terang. Oleh karena itu, diperlukan penjelasan-penjelasan mengenai Alquran seperti pada masa Rasululah saw., semua arti kata-kata tertentu dalam ayat-ayat, hubungannya dengan masalah-masalah yang timbul, seluk-beluk sejarah tertentu, kerohanian yang dicari dan keterangan yang jauh dan jelas. Jawaban semua itu tersimpan baik dalam ingatan para sahabat yang kemudian dituliskan. Generasi berikutnya yaitu tabiin yang menyusun mata rantai dalam rangka mencari keterangan. Dengan demikian, para sahabat pun ada yang benar-benar mengenal apa yang dimaksud oleh Rasulullah, sehingga digelari mufasir. 
Dalam penerjemahan, setiap penerjemah diharapkan memahami sedekat mungkin naskah asli yang diterjemahkan. Setiap penerjemah yang sungguh-sungguh berhak menggunakan semua pengetahuannya dan pengalaman yang dimilikinya untuk memahami Alquran. Namun demikian, kadang-kadang dalam menerjemahkan teks-teks masih juga mengalami beberapa kesulitan di antaranya:

- Kata-kata bahasa Arab yang ada dalam Alquran mempunyai arti lain dari yang dipahami oleh Rasulullah. Hal ini dapat dimengerti karena semua bahasa itu mengalami transformasi sehubungan dengan perkembangan penutur bahasa yang bersangkutan.

- Sehubungan dengan perkembangan transformasi bahasa Arab, ahliahli tafsir berikutnya banyak meninggalkan penafsiran-penafsiran terdahulu tanpa ada alasan yang cukup jelas.

- Setiap akar kosakata bahasa Arab klasik begitu luas sehingga sulit sekali memperoleh diksi kosakata dalam penerjemahan ke dalam bahasa modern secara analitis kata demi kata atau memakai kata yang sama dengan bahasa asalnya dalam nash Alquran.

- Setiap terjadi kekeliruan atau bertolak belakang dalam beberapa materi tertentu dalam kosakata Alquran yang begitu kaya yang membedakan antara pengertian benda dan gagasan tertentu dengan kata-kata yang khusus, yang juga dalam bahasa Inggris merupakan kata yang umum.

- Tujuan Tuhan itu abadi dan perencanaan-Nya sempurna, sedangkan akal manusia itu terbatas pada tingkat yang sebaik-baiknya. Dalam pribadi seseorang yang sama intelek dapat tumbuh ataupun merosot bergantung pada kekuatan atau keluasan pengalamannya.

\section{Pendekatan yang Digunakan Abdullah Yusuf Ali dalam Menerjemahkan Alquran}

Abdullah Yusuf Ali telah menerjamahkan Alquran dari bahasa Arab sebagai bahasa sumber ke dalam bahasa Inggris sebagai bahasa sasaran. Ia menerjamahkan sesuai dengan terjamah, yakni mengartikan kosakata secara leksikal dengan tidak menafikan pengertian gramatikal, kontekstual dan kondisi sosio-kultural, sehingga terlepas dari pelarangan atau haramnya terjamah kosakata secara harfiah. 
Abdullah Yusuf Ali menterjamahkan Alquran dengan ulasan yang puitis dalam jumlah ayat yang cukup banyak. Ia telah mengulas terjamahannya dalam bentuk numeralisasi sebanyak 300 ulasan dalam bentuk syair, ulasan ini dibuat pada setiap ayat yang dianggap perlu. Umpamanya, surah Yasin yang terdiri atas 83 ayat, mulai dari introduction to sura xxxvi (Yasin) pada halaman 1168 sampai dengan halaman 1188. Ulasan yang dibuat dan dibagi dari ayat 1 sampai dengan 32 pada halaman permulaan dalam surat ulasan no.194. Ulasan berikutnya dibuat dalam surat yang sama yang dibuat dari ayat 33 sampai dengan 50 dalam ulasan nomor 195 pada halaman 1177. Ulasan berikutnya dari ayat 51 sampai dengan ayat 83 dengan nomor ulasan 196 itu pada halaman 1181. Selain itu, ia membuat catatan kaki dari awal surah sampai sampai akhir surah dalam 30 juz Alquran sebanyak 6311 catatan. Dalam contoh surah tersebut di atas dapat dilihat beberapa banyak catatan kaki yang telah dibuatnya. Catatan kaki mulai dari nomor 3943 pada ayat I surah yang bersangkutan sampai catatan kaki nomor 4029 pada halaman 1188.

Ulasan Abdullah Yusuf Ali ini merupakan penjelasan umum yang mencakup makna leksikal, gramatikal, kontekstual dan sosialkultural sehingga memberi kesan para penerjemah tetap terikat kepada bahasa baku dalam Alquran. Dengan demikian, terjamahan harus mematuhi kaidah-kaidah bahasa Alquran, sedangkan tafsir yaitu interpretasi dari terjemahan tersebut disajikan di samping sebagai ulasan.

Catatan kaki merujuk kepada sumber dari pembahasan. Catatan kaki itu dapat merupakan sumber kutipan dalam pembahasan atau uraian sehingga jelas dari makna seorang penulis mengutip serta terhindar dari perbuatan "kriminal ilmiah" (plagiat). Di samping itu, catatan kaki juga berarti penjelasan sesuatu dalam bahasan atau uraian yang dianggap penting bagi yang memerlukannya. Sesuatu dalam pembahasan atau uraian itu biasanya berbentuk konsep atau istilah yang memerlukan penjelasan. Adapun catatan kaki yang digunakan oleh Abdullah Yusuf Ali lebih cenderung kepada penjelasan arti kosakata sehingga terhindar dari makna leksikal atau harfiah saja. Catatan kaki adalah cara penafsirannya dalam bentuk catatan bawah yang banyak membuka cakrawala pikiran pembacanya dan yang menyebabkan tafsir ini menduduki tempat yang tinggi dan menjadi acuan penting. 
Untuk memperoleh gambaran tentang apa dan siapa Abdullah Yusuf Ali dalam kaitannya dengan penguasaan bahasa Arab dan bahasa Inggris serta pembelajaran berbagai terjemahan kitab-kitab suci dapat digambarkan sebagai berikut.

Setelah itu, ia mengembara ke kota-kota besar di Eropa dan kemudian menetap di London. Di ibu kota Inggris ini ia tinggal cukup lama. Ia mengenal baik kebudayaan Barat dan falsafahnya. Ia bergaul dengan pemuka agama lain dan mendapatkan kesempatan yang lebih baik mempelajari berbagai terjamahan kitab-kitab suci mereka dengan tekun, sehingga dapat dikatakan banyak yang sudah dihafalnya, selain minatnya yang tak putus-putusnya yang hendak memperdalam Alquran dan segala sesuatunya yang berhubungan dengan hal itu.

Cukup lama ia menekuni pengajian mengenai Alquran dan mengenai seluk-beluk tafsirnya yang klasik dan mutakhir yang ditulis dalam bahasa-bahasa Barat dan Timur. Semua ini diserapnya dengan baik sekali. Abdullah Yusuf Ali juga dikenal sebagai seorang peminat sastra terutama sastra Persia dan Inggris Klasik. Dia mengenal baik sekali karya-karya Shakespeares dan puisi-puisi Milton, Wordsworth, Shelley, Tennyson, Keats dan yang lain (Audah,1993:v).

Kemudian dari itu, Penjaga kedua Mesjid Suci Raja Fahd ibn 'Abd al-'Azîz al-Su'ûd Raja Kerajaan Saudi Arabia melalui King Fahd Holy Qur'an Printing Complex memuat pernyataan sebagai berikut:

Satu-satunya acuan Abdullah Yusuf Ali dalam edisi ini adalah pada catatan pada pengantar yang dipersiapkan oleh kepresidenan. Terjamahan dari Abdullah Yusuf Ali, dipilih sebagai terjamahan yang dapat dipercaya karena ciri-cirinya yang menonjol, yaitu gayanya yang sangat anggun, pilihan kata-katanya yang dekat dengan makna dan teks aslinya disebabkan karena tejemahan itu disertai catatan dan ulasan ilmiah (Syerif,1994:232).

\section{Karakteristik Tafsir}

The Holy Qur'an, karya Abdullah Yusuf Ali ini, memiliki karakteristik tidak seperti kebanyakan tafsir yang ditulis dalam bahasa Arab karena memiliki ciri-ciri tertentu sebagai berikut:

- dimulai dari pengantar, isi, dan penutup. Tafsirnya diakhiri dengan menyertakan indeks analisis untuk membantu pembaca menemukan semacam short-cut tema-tema yang ingin dikaji; 
- topik-topik yang ingin ditulis pada bagian awal: Tafsir Alquran, terjemahan dan buku acuan (sejarah perkembangan terjemah);

- mengungkapkan pandangan/kritikan terhadap karya terdahulu;

- kitab tafsir fortable yang merupakan ciri khas yang ditonjolkan;

- memberikan catatan-catatan tafsir yang bagian bawah dibuat padat dan berusaha menghindari komentar yang kurang releven dengan yang dibahas;

- lebih banyak membahas persoalan spiritual;

- menghindari perdebatan teologis, legalistik, linguistik-gramatikal dan filologi yang uraiannya bersifat teknis sengaja disingkirkan;

- mengungkap asbâb al-Nuzûl untuk membantu memahami teks.

\section{Corak Tafsir}

The Holy Qur'an adalah tafsir yang bercorak spritual/sufistik. Penafsiran-penafsiran spritualnya banyak berfokus pada simbolsimbol yang terungkap dalam Alquran. Pikiran ini didasarkan pada kenyataan bahwa Alquran itu seluruhnya merupakan ayat-ayat (tandatanda) Allah. Hal ini membuat Abdullah Yusuf Ali sangat tertarik kepada semua yang dipandang sebagai simbol di dalam Alquran dan melakukan takwil atas simbol-simbol itu serta memberi tekanan pada makna batinnya "hermeneutika eksoterik".

Abdullah Yusuf Ali menggunakan beberapa istilah untuk mengacu kepada bahasa simbolis Alquran, seperti metafora (metaphor), alegori (allegory), di samping simbol (symbol) dan makna yang figuratif (figurative meaning, figurative word). Semua istilah ini mengandung pengertian bahwa makna yang dimaksud oleh suatu kata bukanlah makna harfiah, melainkan makna lain di baliknya.

Dari satu perspektif dapat dikatakan bahwa makna lain di balik pengertian literal itu adalah kualitas-kualitas spiritual atau kebenarankebenaran rohani atau kenyataan-kenyataan tinggi (high realities). Analogi langit dan bumi, seperti yang dikemukakan di atas. Berarti perlu adanya kebenaran-kebanaran rohani yang tergantung dari kebenaran yang tinggi sampai kepada yang paling rendah dan kasar dari ciptaan-Nya. Realitas-realitas tertinggi seperti surga dan neraka, pahala dan dosa, akhirat dan keadilan, semua itu mungkin dipahami dengan ungkapan-ungkapan metaporis berupa perumpamaanperumpamaan (mithâlât) seperti yang terdapat dalam Alquran surah Al-Zumar (39):27: 


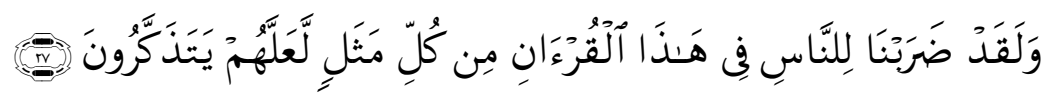

\author{
Abdullah Yusuf Ali menafsirkan ayat "Min Kulli Matsal" \\ dengan:
}

"Men can only understand high spiritual truths by parables and similitudes and these are given abundantly in the Qur'an. The object is not merely to tell stories, but to teach lessonc of spiritual wisdom"

Manusia dapat memahami kebenaran rohani yang tinggi hanya dengan perumpamaan-perumpamaan (parabel-parabel) dan majas-majas (similitudes) dan semua ini terdapat banyak sekali dalam Alquran, tujuannya bukan hanya menceritakan kisah-kisah, melainkan untuk mengajarkan kebaijaksanaan rohani.

Abdullah Yusuf Ali tidak mengingkari pemaknaan fisik atas ayat-ayat Alquran. Ia membenarkan pengertian fisik, namun ia memberikan penekanan yang lebih kuat pada makna rohaninya. Hal ini tampaknya, karena Abdullah Yusuf Ali tertarik pada kenyataan bahwa Alquran merupakan ayat-ayat (tanda-tanda Allah), yang berarti bahwa firman-rirman Allah itu tidak hanya merupakan pernyataan fisikal. Allah juga mengungkapkan kenyataan-kenyataan spiritual (sisi batin ayat), yang fisikal dan spiritual dibedakan bukan dalam pengertian yang dualisme, dimana yang satu benar-benar dari yang lain. Bahkan keduanya menampakkan keserasian dan integritas dalam arti kenyataan-kenyataan fisik sepadan dengan kenyataan-kenyataan spiritual.

Penggunaan takwil untuk memahami Alquran dimungkinkan Alquran menjalin hubungan maknawi antara 3 realitas, yaitu Allah, kosmos, dan manusia. Tugas utama manusia adalah mengabdi pada realitas tertinggi mengenai-Nya. Pengertian inilah yang menyimpulkan sebagai tanda-tanda Allah. Artinya, pengertian yang ditunjuk oleh bahasa Alquran yang simbolik itu, tidak secara intrinsik yang terdapat dalam bahasa itu sendiri, tetapi terdapat dalam realitas.

Ada satu cara penafsiran yang sangat menarik dalam konteks sekarang ini, yakni takwil (al-Shâbûnî, t.th.:89), yang kadang-kadang disebut dengan "hermeneutisme esoterik" (Murata,1996:300). Sebagian ulama tafsir menyamakan arti antara tafsir dengan takwil. Kedua istilah ini dianggap bermakna penjelasan atau keterangan tentang Alquran. Tetapi jika perbedaan itu dilihat diantara keduanya, 
takwil sering dikatakan mengacu pada pembacaan ayat-ayat Alquran dengan emperhatikan implikasi-implikasi yang tersembunyi di bawah atau di balik makna harfiyah. Atau, kemungkinan tafsir adalah ulasan yang didasarkan atas apa yang diturunkan pada kita lewat tradisi, sementara takwil menambah dimensi perenungan pribadi (Murata,1996:300).

\section{Rujukan dalam Tafsir}

Dalam menulis tafsirnya, Abdullah Yusuf Ali mengambil dari berbagai sumber sejauh yang dapat dikumpulnya menyangkut tematema atau ilmu yang terkait dengan bahasan Alquran. Sumber-sumber yang digunakan tidak terbatas pada sumber klasik dan tidak juga terbatas pada sumber kepustakaan. Ia melakukan perjalanan ke tempat-tempat tertentu untuk menghayati pesan makna Alquran. Wawancara kepada orang yang dianggapnya ahli atau otoritatif juga dilakukannya untuk mendalami bidang-bidang tertentu untuk ditafsirkannya.

Di antara kitab tafsir yang dijadikan rujukan Abdullah Yusuf Ali ialah antara lain:

- Tafsîr al-T $\square$ abârî: Ibnu Jarîr al-T $\square$ abârî (w. 310 H.) yang memfokuskan pada sumber informasi sejarah yang lengkap, karena penulis ini adalah seorang ahli sejarah.

- Mufradât al-Qur'ân: Raghîb al-Ishfahânî (w. 503 H.) merupakan kamus kosakata dan ungkapan-ungkapan yang sulit dalam Alquran, termasuk kata-kata kiasan.

- Tafsîr al-Kashshaf: Abû Qâsim Mah $\square$ mûd al-Zamakhsharî (w. 538 H.) merupakan suatu tafsir yang berisikan penjelasan mengenai kalimat, ungkapan dan ajaran yang rasional dan etika yang jelas. Tafsir ini juga dikenal dengan tafsir yang beraliran Mu'tazilah

- Tafsîr al-Kabîr: Fakhr al-Dîn Muh $\square$ ammad al-Râzî (w. 606 H.) Tafsir ini juga dikenal dengan nama Tafsîr Mafâtih al-Ghayb, Sesuai dengan keahliannya dalam hal ilmu filsafat dan ilmu alam, maka dalam menafsirkan sarat ditemukan penjelasan-penjelasan ayat kauniyah dengan bahasan yang luas, sekaligus melakukan kritis terhadap pendapat para filosof.

- Anwâr al-Tanzîl: Qâd $\square$ i al-Qud $\square$ ât Nash al-Dîn Abû Khayr 'Abd Allâh bin Umar bin Muh $\square$ ammmad bin 'Alî al-Baid $\square$ âwî al- 
Shâfî̀ (w. 685 H.) Tafsir ini juga dikenal dengan Anwâr al-Tanzîl wa Asrâr al-Ta wîl. Dalam metode penafsiran beliau dapat dikategorikan sebagai tafsir bi al-ra'y dan tafsir bi al-ma'qûl yang tidak seratus persen menyandarkan pendapatnya pada hasil penalaran akal semata.

Tafsîr Ibnu Kathîr: Imâd al-Dîn Abû Fida' Ismâ'îl bin Kathîr al-

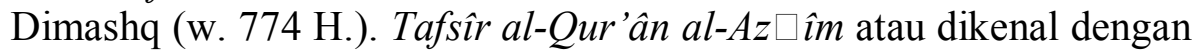
Tafsîr Ibnu Kathîr adalah kitab yang paling banyak dikutip dan dijadikan rujukan oleh para ulama.

- Tafsîr al-Manâr: Muhammad Abduh dan Rashîd Ridâ. Di dalam al-Manâr, Muhammad Abduh hanya menafsirkan sampai dengan juz dua belas dari Alquran, dan kemudian dilanjutkan oleh muridnya Rashîd Ridâ. Tafsir ini bercorak adab al-Ijtimâ $\hat{\imath}$ karena banyak memuat masalah-masalah sosial kemasyarakatan.

- Di samping kitab-kitab yang disebut di atas, Abdullah Yusuf Ali berpandangan bahwa Alquran itu adalah penafsir dirinya yang terbaik.

- Dan masih banyak tafsir dan kitab-kitab, baik berbahasa Inggris maupun berbahasa Arab. Di antaranya: al-Mufradât, Lisân al-Arab, Dictionary dan Glossary of the Koran oleh J. Penrice, EnglishArabic Lexicom oleh E.W. Lane, al-Itqân fî Ulûm al-Qur'ân oleh Jalâl al-Dîn al-Suyut $\square \hat{1}$, Encyclopaedia of Islam, Encyclopaedia Britannica, dan lain-lain.

\section{Contoh-contoh Penafsiran}

Dalam Alquran disebutkan bahwa Tuhan adalah cahaya di atas cahaya. Cahaya yang memancar dari sumber-sumber yang berbeda akan memiliki kekauatan dan ketajaman yang berbeda akan pemilik kekuatan dan ketajaman berbeda pula. Sikap rohani yang paling baik menurut Abdullah Yusuf Ali adalah sikap menyusuaikan diri, dalam arti mengimani, menyesuaikan diri, dalam arti mengimani dan tidak menginkarinya. Abdullah Yusuf Ali (1980:43) mengatakan:

Orang yang harus menyesuaikan diri dengan sinar atau cahaya Rohani (spiritual light), bukan malah menaru curiga atau merugikan chaya Iman berupa wahyu. Itulah sikap spiritual manusia yang harus ditunjukkan dalam menghadapi persoalan rohani. Namun, jika mereka bersikap sebaliknya, menentang (spiritual faith) dan menjadi kafir, maka mereka telah menyulut api dalam jiwa sebagai hubungannya dan akan menghabis mereka. 
Di sini Abdullah Yusuf Ali menyatakan bahwa orang yang tidak dapat menyesuaikan diri dengan cahaya rohani, bahkan menolak iman dan memilih kafir maka yang ada hanyalah api dalam jiwanya.

Abdullah Yusuf Ali mengilustrasikan bahwa Tuhan dalam realitas spiritual, adalah Cahaya (the Light). Namun demikian, cahaya yang dimaksud di sini lebih merupakan simbol atau farabel, meskipun Allah menggunakan kata ini untuk menyebut diri-Nya. Dengan demikian, bagi Abdullah Yusuf Ali, penyebutan "cahaya" untuk Allah hanyalah dalam pengertian simbolik. Dalam hal ini ia menegaskan: "No notes can do adequate justice to its full meaning". Di sini dinyatakan "cahaya sesungguhnya yang agung, tak terbatas, tak dapat dilukiskan atau diukur. Cahaya itu berlapis-lapis melalui daerah spiritual yang tinggi secara trasenden (region of spiritual height) yang tak dapat ditanggap oleh imajinasi. Puncaknya yang tertinggi adalah cahaya yang asli sebenarnya, cahaya yang nyata, sehingga segala yang lain hanyalah merupakan pantulan, yakni cahaya Allah (Ali,1980:3003).

Dalam sebuah hadis dalam shahih Muslim hadis no. 261 diceritakan bahwa ketika Abu Dzar bertanya kepada Rasulullah saw. Apakah beliau melihat Tuhan, nabi menjawab cahaya yang kulihat. Teks hadisnya:

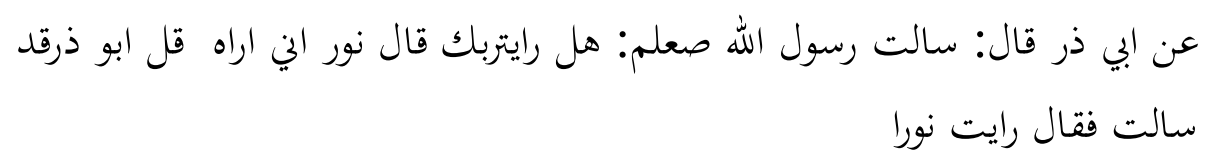

Dan hanya Tuhanlah yang paling tepat untuk disebut cahaya. Pemikiran Abdullah Yusuf Ali dalam tafsirnya tampaknya mencerminkan perspektif kaum kearifan, yang di satu sisi menjadikan perspektif ketakterbandingan sebagai pijakan, dan selebihnya menekankan perspektif keserupaan. Mengenai perspektif ketakterbandingan Tuhan, Abdullah Yusuf Ali mengomentari Q.S 59 22:

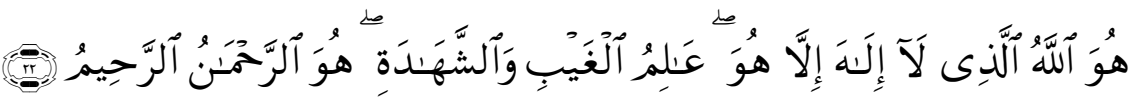


Ayat ini merangkum sifat-sifat Allah, dan ini merupakan sifat umum yang menyuguhkan basis fundamental untuk membentuk gagasan-gagasan tentang Allah. Mulai dari pernyataan bahwa tiada yang serupa dengan-Nya (Ali, 1980:5400).

Dengan pemahamn seperti itu, Abdullah Yusuf Ali mencoba menyentuh berbagai pengalaman sosio-spiritual dalam masyarakat manusia dalam mempresepsi dan berhubungan dengan kenyataan spiritual, yang dalam pengamatannya mencerminkan berbagai perspektif, termasuk kesalahan-kesalahan perspektif manusia dalam dunia spiritual.

Dalam perspektif kosmologi Islam, seperti halnya dengan setan, jin dan malaikat menempati dunia tak terlihat, dan masing-masing mewakili sifat Allah tertentu. Dari satu sisi mereka mewakili sifat batin Allah. Namun dari sisi lain, makhluk-makhluk rohani mewakili sifat-sifat yang berbeda dari sifat-sifat Allah. Meskipun Yusuf Ali menganut pemahaman umum mengenai eksistensi malaikat, penyebutannya dalam Alquran dalam pandangan Abdullah Yusuf Ali ada yang bersifat hakiki dan majazi. Yang bersifat hakiki merujuk kepada makhluk malaikat itu sendiri, dan yang majazi merupakan simbol yang merujuk kepada manusia yang memiliki karakteristik kebaikan, kemuliaan, kelembutan, keilmuan dan kekuasaan, seperti Harut dan Marut (Ali, 1980:102).

Dalam Alquran banyak ditemukan kata roh dan ilmu jiwa dalam tasawuf, dengan beberapa variasi. Menurut al-Najjâr (2000:55-56), dalam Alquran ada 25 kata roh dengan beberapa makna. Varian tersebut menyebabkan tafsiran berbeda-beda dan beragam. Dalam tafsir The Holy Qur'an, Abdullah Yusuf Ali mengartikan roh dengan spirit, misalnya pada Q.S 4:171, 15:29, 70:4, 78:38 dan 97:4. roh yang dimaksud adalah roh Allah, seperti apa yang dihembuskan kepada nabi Adam pada proses penyempurnaan penciptaannya, dan sebagai ketinggian dan kemuliannya dibandingkan dengan makhluk lain.

Dalam mengkaji pemahaman Abdullah Yusuf Ali mengenai akal, ia menerjemahkan kata ini dengan beberapa variasi. Variasi ini tampaknya dipengaruhi oleh konteks ayat di mana kata tersebut berada. Di beberapa tempat Abdullah Yusuf Ali menerjemahkannya 
dengan "paham" atau "memahami" (to understand), misalnya pada Q.S 2:44, 73, 76, 164, 242, 3:65, 5:58, 10:42, 100, 11:51, 13:14, 21:10, 23:80. kadang juga diartikan memiliki kearifan (to have wisdom) seperti dalam Q.S 3:118, atau mempelajari kearifan (to learn wisdom) dalam Q.S 6;151, 12;2, 22;46, 43;3, 57;17. di tempat lain di samping menggunakan wisdom untuk kearifan void of wisdom) dalam Q.S 2:171, atau mengunci kearifan (to lock wisdom) dalam Q.S 59:14. frase itu juga diartikan oleh Abdullah Yusuf Ali "tidak memiliki intelegensi" (have no intelligence), seperti dalam 39:43 dan 67:10

Berdasarkan corak terjemahan tersebut maka dapat dikatakan bahwa Abdullah Yusuf Ali menekankan akal sebagai alat untuk memperoleh kebijaksanaan (wisdom) atau hikmah, seperti dalam filsafat

Yang menarik dari pendapat Abdullah Yusuf Ali mengenai akal ini adalah akal dapat melenceng dari kebenaran sehingga harus diwaspadai dengan jalan mengontrol fungsionalisasinya ke arah yang sejalan dengan perintah-perintah Allah.

\section{DAFTAR PUSTAKA}

Audah, Ali. 1993. Qur'an-Terjamahan dan Tafsirnya. Jakarta: Pustaka Firdaus.

Hidayat, Komaruddin. 2004. Menafsirkan Kehendak Tuhan. Cet. II. Jakarta: Penerbit Teraju.

Murata, Sachiko. 1996. The Tao of Islam, Kitab Rujukan tentang Relasi Gender dalam Kosmologi dan Teologi Islam. Cet. I. Bandung: Penerbit Mizan.

al-Najjâr, Amîr. 2000. Al-'Ilm al-Nafs al-Sûfiyah. Cairo: Dâr al-Ma'ârif, t.th. Terjemahan oleh Hasan Abrori. Jakata: Pustaka Azzam.

Shihab, M.Quraish. 2002. "Kata Pengantar I" dalam buku Rasionalitas Tafsir Muhammad Abduh, Kajian Masalah Akidah dan Ibadat. Cet. I. Jakarta: Penerbit Paramadina. . 1996. Membumikan Alquran, Fungsi dan Peran Wahyu dalam Kehidupan Manusia. Cet. XII. Bandung: Mizan.

Sherif, MA. 1994. Searching the Solace: A Biography of Abdullah Yusuf Ali, Interpreter of the Qur'an. Kuala Lumpur: Book Center Trust. 
Jurnal Hunafa, Vol. 7, No.1, April 2010:1-24

Yusuf Ali, Abdullah. 1989. "Preface to First Edition", The Holy Qur'an. Brentwood, Maryland, USA: Amana Corpuration.

. 1980. The Holy Qur'an: Text, Translations and Commentary. Lahore, Pakistan, Kasymiri Bazar: Ashraf Printing Press.

al-Sâbûnî, Muhammad 'Alî. t.th. Al-Tibyân fì 'Ulûm al-Qur'ân. Riyad $\square$ : Dâr al-Kutub. 